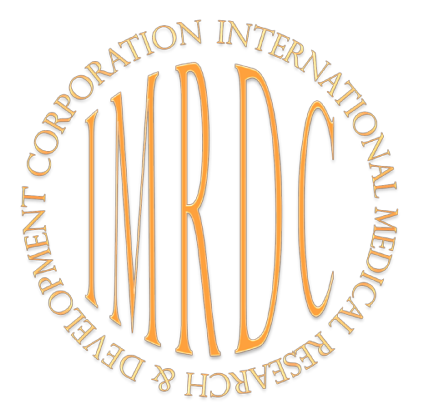

\title{
Interaction of Long-Chain Alcohol with Dry Yeast, Cholesterol, and Sea Firefly Luciferase
}

\author{
Kibo Nagasaki ${ }^{1}$; Shinya Nagasaki ${ }^{*}, \mathrm{PhD}$ \\ ${ }^{1}$ Oakville Christian School, Oakville, Ontario, Canada \\ (Current Affiliation: Mentor College, Mississauga, Ontario, Canada) \\ ${ }^{2}$ Department of Engineering Physics, McMaster University, Hamilton, Ontario, Canada
}

\begin{abstract}
Background: A hand sanitizer containing alcohol, usually ethanol or isopropanol, is typically used for disinfection, but given that cholesterol is one of the main components of virus envelopes, long-chain alcohol may be more effective. To better understand the potential disinfection activity of long-chain alcohols, we studied their interactions with dry yeast, cholesterol, and sea firefly luciferase.

Methods and Results: We measured, at $30{ }^{\circ} \mathrm{C}$ and $39{ }^{\circ} \mathrm{C}$, the minimum inhibition concentration (MIC) of dry yeast fermentation and the stability of cholesterol and sea firefly luciferase with alcohols, diols, cetyltrimethylammonium chloride, and stearyltrimethylammonium chloride. The MIC decreased with the chain length at $\mathrm{C} \leq 12$ for dry yeast and cholesterol with alcohol at $30^{\circ} \mathrm{C}$. At $\mathrm{C}_{13}$ and higher, the cut-off region was observed. At $39^{\circ} \mathrm{C}$, the cut-off region shifted to $\mathrm{C}_{15}$ and higher. The reduction of MIC was measured with the diol or sea firefly luciferase at $\mathrm{C} \leq 14$.

Conclusion: The presence of the cut-off region is suggested to be related to whether the alcohol is in the liquid state. For the liquid alcohol, the longer the chain length, the lower the MIC. This suggests a potential disinfection activity of long-chain alcohol. (International Journal of Biomedicine. 2021;11(4):460-466.)
\end{abstract}

Key Words: cut-off region • liquid alcohol • minimum inhibition concentration

For citation: Nagasaki K, Nagasaki Sh. Interaction of Long-Chain Alcohol with Dry Yeast, Cholesterol, and Sea Firefly Luciferase. International Journal of Biomedicine. 2021;11(4):460-466. doi:10.21103/Article11(4)_OA12

\section{Introduction}

During the COVID-19 pandemic, people are recommended to wash their hands with soap or an alcoholbased hand sanitizer. ${ }^{(1)}$ The viral envelope of the COVID-19 virus is lipophilic/hydrophobic due to its composition of lipids and cholesterol. However, a question arises as to why we use ethanol or isopropanol but not long-chain alcohols.

The effects of ethanol and isopropanol on disinfection have been widely studied, reviewed, and summarized. ${ }^{(2-8)}$ However, only a few studies have investigated the effect of long-chain alcohols. Kubo et al..$^{(9)}$ investigated the antimicrobial activity of long-chain alcohols and reported

*Corresponding author: Prof. Shinya Nagasaki, PhD. Department of Engineering Physics, McMaster University, Hamilton, Ontario,Canada.E-mail:nagasas@mcmaster.ca only the trend and qualitative results from the standpoint of the alcohol structure. Using alcohols, Mukherjee et al. ${ }^{(10)}$ investigated the antibacterial properties of long-chain fatty alcohols against mycobacteria. Mukherjee et al. ${ }^{(10)}$ found that the best activity was shown by alcohol with a $\mathrm{C}_{10}$ chain length, but this was not consistent with the report by Kubo et al. ${ }^{(9)}$ Fletcher et al. ${ }^{(11)}$ studied the inhibitory activity of longchain alcohols on the growth of Mycoplasma gallisepticum and Mycoplasma pneumoniae and found that the primary saturated alcohols were more effective than both the unsaturated and secondary alcohols. However, the reason for this difference was not clear. Ingram and Vreeland ${ }^{(12)}$ compared the effects of ethanol with that of hexanol only on the inhibition of the growth of Escherichia coli. Gill and Ratledge, ${ }^{(13)} \mathrm{Teh}^{(14)}$ and Kato and Shibasaki ${ }^{(15)}$ studied the inhibition of growth of various microorganisms by $n$-alcohols and found that the inhibition potency increased with the chain length. In sum, few studies have been conducted on 
the activity of long-chain alcohols from the perspective of disinfection, and the effect is not fully understood.

Many previous studies delved into the impact of longchain alcohol on the anesthetic effects (a local or general loss of sensation, including pain, achieved by action on the brain or peripheral nervous system to suppress responses to sensory stimulation) $)^{(16-18)}$ and the growth of microorganisms ${ }^{(9,19)}$ and reported the presence of a cut-off region (i.e., where alcohols or other compounds suddenly lose their activity and function). However, the reason for this cut-off phenomenon in anesthetic effects and microorganism growth is unknown although some explanations have been proposed. ${ }^{(18,20-22)}$ Furthermore, to the best of our knowledge, no previous study has investigated whether the cut-off is observed in the case of disinfection with long-chain alcohol.

According to Veenstra et al., ${ }^{(23)}$ the long-chain alcohols showed low acute and repeat-dose toxicity with high-dose effects related to minimal liver toxicity. There was no evidence of toxicity to the reproductive system or the developing organism with these chemicals. The former was performed on male and female rats during premating, mating, and gestation. For up to a year, the latter was studied with rats and dogs. Alcohols with $\mathrm{C}_{6}-\mathrm{C}_{11}$ chain lengths are generally considered irritants, whereas those with intermediate chain lengths $\left(\mathrm{C}_{12}-\right.$ $\mathrm{C}_{16}$ ) are considered mild irritants. These chemicals are broadly and safely used across the consumer products industry with the highest per person consumer exposures resulting from use in personal care products.

Therefore, to understand the activity of long-chain alcohol for disinfection, the dependence of the minimum inhibitory concentration (MIC) on the chain length of alcohol should be studied. Further, we should examine whether the cut-off region is present, and if it is, explain the reason for its presence.

In this work, we studied the MIC of alcohol for dry yeast fermentation and cholesterol stability, examined whether a cut-off region existed, and if yes, investigated the reason for the existence of the cut-off region. This study provides no direct evidence of the efficacy of long-chain alcohols as disinfectants. We believe, however, that it can present new and basic data for discussing a potential activity and possibility of these alcohols for disinfection.

In many studies on disinfection, real microorganisms, bacteria, and viruses were used. Some studies ${ }^{(24,25)}$ have shown that dry yeast can be used to study disinfection, antimicrobial action, and infectious diseases. Moriyama ${ }^{(26)}$ developed biological control materials and used mycovirus and dry yeast to prevent virus-induced rice diseases. The inhibitory effect of alcohols on mycoplasmas was investigated using cholesterol. ${ }^{(11)}$ Furthermore, cholesterol is one of the main components of the envelope of viruses such as SARS-CoV-2. Therefore, we used dry yeast and cholesterol instead of real viruses. In this study, we also used dried sea firefly luciferase.

\section{Materials and Methods}

\section{Chemicals}

In this study, straight-chain alcohols and diols, cetyltrimethylammonium chloride, and stearyltrimethylammonium chloride were used. All chemicals listed in Table 1 (except 1,4-butanediol, 1,6-hexanediol, and 1,16-hexadecanediol), $N, N$-dimethylformamide (DFM), $\mathrm{pH}$ buffer solution ( $\mathrm{pH} 6$ ), cholesterol, and cholesterol fluorescence kit were purchased from Fisher Scientific Canada. MilliporeSigma supplied three diols for this experiment. Dried sea firefly was purchased in Monotaro, Japan. The Metro Supermarket supplied dry yeast (Instaferm by Lallemand Inc.) and sugar (granulated sugar by Lantic Sugar Ltd.) (Oakville, Ontario, Canada). Milli-Q Direct 8 equipment was used to create deionized water.

\section{Solutions}

The concentrations of ethanol, 1-butanol, 1,2-ethanediol, and 1,4-butanediol were adjusted by diluting the original solutions with deionized water. The long-chain alcohols, diols $\left(\mathrm{C}_{6} \leq\right.$ chain length $\left.\leq \mathrm{C}_{16}\right)$, cetyltrimethylammonium chloride, and stearyltrimethylammonium chloride were first dissolved in DFM and then their concentrations were adjusted. Since the fermentation of dry yeast is the most active at a $\mathrm{pH}$ of $\sim 6$, the $\mathrm{pH}$ buffer solution $(\mathrm{pH}=6)$ was added to all solutions. The final concentration of DFM was $1 \%$. It was previously confirmed that the $\mathrm{pH}$ buffer solution and 1\% DFM do not affect the fermentation of dry yeast or the stability of cholesterol and sea firefly luciferase.

Based on the preliminary tests, the concentrations of chemicals were decided as listed in Table 1 at first. Using the chemicals listed in Table 1, the lower limit of MIC was determined, below which dry yeast fermentation and the stability of cholesterol and sea firefly luciferase were observed, and the upper limit of MIC was determined, above which these characteristics were not observed. The chemicals were then prepared with concentrations that were slightly finely adjusted between the upper and lower limits of the MIC, and the experiment was repeated. The upper limit of the MIC decided with these slightly, finely adjusted concentrations was adopted as the final MIC value.

\section{Minimum inhibitory concentration}

Ishijima and $\mathrm{Abe}^{(25)}$ demonstrated the use of the culture media, measurement of the growth inhibition circle, and assessment of the MIC for antibacterial, disinfection, and sterilization purposes. We first measured the MIC for dry yeast fermentation with ethanol using the Ishijima and Abe's method $^{(25)}$ and experimental procedure described below, and the MICs measured using both methods were identical. Therefore, in this study, we used the experimental procedure described below. To confirm the reproducibility of MIC, all measurements were performed 10 times in 10 independent and separate experiments.

\section{Dry yeast fermentation}

Five grams sugar and $1 \mathrm{~g}$ dry yeast were added to a 50 $\mathrm{mL}$ centrifuge tube. After $10 \mathrm{~mL}$ alcohol solution was added to the tube, the tube was put in the incubator for $30 \mathrm{~min}$. The temperature was controlled at $30^{\circ} \mathrm{C}$ or $39^{\circ} \mathrm{C}$.

After 30 min of fermentation, the MIC was determined to be the lowest concentration that completely inhibited the fermentation of dry yeast.

The same procedure was applied with diols, cetyltrimethylammoniumchloride, orstearyltrimethylammonium chloride at $30^{\circ} \mathrm{C}$. The solubilities of cetyltrimethylammonium 
chloride and stearyltrimethylammonium chloride are higher than those of alcohols with $\mathrm{C}_{16}$ and $\mathrm{C}_{18}$.

\section{Table 1.}

\section{Concentrations of chemicals}

\begin{tabular}{|c|c|c|}
\hline Chemicals & Target & Concentrations (M) \\
\hline ethanol & & $1 \times 10^{-2}, 1 \times 10^{-1}, 1,1.5,2,7$ \\
\hline 1-butanol & & $\begin{array}{l}1 \times 10^{-2}, 5 \times 10^{-2}, 1 \times 10^{-1}, 5 \times 10^{-1}, 8 \times 10^{-1} \\
1,2\end{array}$ \\
\hline 1-hexanol & & $1 \times 10^{-3}, 1 \times 10^{-2}, 3 \times 10^{-2}, 5 \times 10^{-2}, 1 \times 10^{-1}$ \\
\hline 1-octanol & & 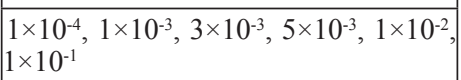 \\
\hline 1-decanol & & $\begin{array}{l}1 \times 10^{-5}, 5 \times 10^{-5}, 8 \times 10^{-5}, 1 \times 10^{-4}, 5 \times 10^{-4}, \\
1 \times 10^{-3}\end{array}$ \\
\hline 1-dodecanol & & $\begin{array}{l}1 \times 10^{-6}, 5 \times 10^{-6}, 1 \times 10^{-5}, 2 \times 10^{-5}, 5 \times 10^{-5}, \\
1 \times 10^{-4}\end{array}$ \\
\hline 1-tridecanol & & $1 \times 10^{-7}, 1 \times 10^{-6}, 3 \times 10^{-6}, 5 \times 10^{-6}, 1 \times 10^{-5}$ \\
\hline 1-tetradecanol & & $\begin{array}{l}1 \times 10^{-7}, 5 \times 10^{-7}, 1 \times 10^{-6}, 2 \times 10^{-6}, 3 \times 10^{-6} \\
5 \times 10^{-6}, 1 \times 10^{-5}\end{array}$ \\
\hline 1-pentadecanol & & $1 \times 10^{-7}, 1 \times 10^{-6}, 1 \times 10^{-5}, 1 \times 10^{-4}$ \\
\hline 1-hexadecanol & & $1 \times 10^{-7}, 1 \times 10^{-6}, 1 \times 10^{-5}, 1 \times 10^{-4}$ \\
\hline 1,2-ethanediol & & $1 \times 10^{-2}, 1 \times 10^{-1}, 1,1.5,2,7$ \\
\hline 1,4-butanediol & $\begin{array}{l}\text { dry yeast } \\
\text { cholesterol }\end{array}$ & $\begin{array}{l}1 \times 10^{-2}, 5 \times 10^{-2}, 1 \times 10^{-1}, 5 \times 10^{-1}, 8 \times 10^{-1}, \\
1,2\end{array}$ \\
\hline 1,6-hexanediol & & $1 \times 10^{-3}, 1 \times 10^{-2}, 3 \times 10^{-2}, 5 \times 10^{-2}, 1 \times 10^{-1}$ \\
\hline 1,8-octaediol & & $\begin{array}{l}1 \times 10^{-4}, 1 \times 10^{-3}, 3 \times 10^{-3}, 5 \times 10^{-3}, 1 \times 10^{-2}, \\
1 \times 10^{-1}\end{array}$ \\
\hline 1,10-decanediol & & $\begin{array}{l}1 \times 10^{-5}, 5 \times 10^{-5}, 8 \times 10^{-5}, 1 \times 10^{-4}, 5 \times 10^{-4}, \\
1 \times 10^{-3}\end{array}$ \\
\hline 1,12-dodecanediol & & $\begin{array}{l}1 \times 10^{-6}, 5 \times 10^{-6}, 1 \times 10^{-5}, 2 \times 10^{-5}, 5 \times 10^{-5}, \\
1 \times 10^{-4}\end{array}$ \\
\hline 1,13-tridecanediol & & $1 \times 10^{-7}, 1 \times 10^{-6}, 3 \times 10^{-6}, 5 \times 10^{-6}, 1 \times 10^{-5}$ \\
\hline 1,14-tetradecanediol & & $\begin{array}{l}1 \times 10^{-7}, 5 \times 10^{-7}, 1 \times 10^{-6}, 2 \times 10^{-6}, 3 \times 10^{-6}, \\
5 \times 10^{-6}, 1 \times 10^{-5}\end{array}$ \\
\hline 1,15-pentadecanediol & & $1 \times 10^{-7}, 1 \times 10^{-6}, 1 \times 10^{-5}, 1 \times 10^{-4}$ \\
\hline 1,16-hexadecanediol & & $1 \times 10^{-7}, 1 \times 10^{-6}, 1 \times 10^{-5}, 1 \times 10^{-4}$ \\
\hline $\begin{array}{l}\text { cetyltrimethyl- } \\
\text { ammonium chloride }\end{array}$ & & $1 \times 10^{-8}, 5 \times 10^{-8}, 1 \times 10^{-7}, 1 \times 10^{-6}$ \\
\hline $\begin{array}{l}\text { stearyltrimethyl } \\
\text { ammonium chloride }\end{array}$ & & $1 \times 10^{-9}, 1 \times 10^{-8}, 5 \times 10^{-8}, 1 \times 10^{-7}$ \\
\hline ethanol & \multirow{10}{*}{$\begin{array}{c}\text { dry sea } \\
\text { firefly } \\
\text { luciferase }\end{array}$} & $1 \times 10^{-2}, 1 \times 10^{-1}, 5 \times 10^{-1}, 8 \times 10^{-1}, 1,2$ \\
\hline 1-butanol & & $1 \times 10^{-3}, 5 \times 10^{-3}, 1 \times 10-2,5 \times 10^{-2}, 1 \times 10^{-1}$ \\
\hline 1-hexanol & & $1 \times 10^{-4}, 5 \times 10^{-4}, 1 \times 10^{-3}, 5 \times 10^{-3}, 1 \times 10^{-2}$ \\
\hline 1-octanol & & $1 \times 10^{-5}, 1 \times 10^{-4}, 5 \times 10^{-4}, 1 \times 10^{-3}, 5 \times 10^{-3}$ \\
\hline 1-decanol & & $1 \times 10^{-6}, 5 \times 10^{-6}, 1 \times 10^{-5}, 5 \times 10^{-5}, 1 \times 10^{-4}$ \\
\hline 1-dodecanol & & $1 \times 10^{-7}, 1 \times 10^{-6}, 1 \times 10^{-5}, 5 \times 10^{-5}, 1 \times 10^{-4}$ \\
\hline 1-tridecanol & & $1 \times 10^{-7}, 1 \times 10^{-6}, 2 \times 10^{-6}, 5 \times 10^{-6}, 1 \times 10^{-5}$ \\
\hline 1-tetradecanol & & $5 \times 10^{-8}, 1 \times 10^{-7}, 5 \times 10^{-7}, 1 \times 10^{-6}, 5 \times 10^{-6}$ \\
\hline 1-pentadecanol & & $1 \times 10^{-8}, 1 \times 10^{-7}, 1 \times 10^{-6}, 1 \times 10^{-5}$ \\
\hline 1-hexadecanol & & $1 \times 10^{-8}, 1 \times 10^{-7}, 1 \times 10^{-6}, 1 \times 10^{-5}$ \\
\hline
\end{tabular}

\section{Stability of cholesterol}

One gram of cholesterol was dissolved in $1 \%$ DFM. After diluting, $1 \mathrm{mM}$ cholesterol solution was prepared. Then, $100 \mu \mathrm{L}$ cholesterol solution was mixed with $10 \mathrm{~mL}$ alcohol or diol in the $15 \mathrm{~mL}$ centrifuge tube. After $30 \mathrm{~min}$ at $30^{\circ} \mathrm{C}$ or $39^{\circ} \mathrm{C}$ (incubator), $100 \mu \mathrm{L}$ of the solution was taken from the tube and fed to the cholesterol fluorescence kit. At McMaster University (Ontario, Canada), the MIC was calculated using a fluorescence spectrometer (excitation: $560 \mathrm{~nm}$, fluorescence: $590 \mathrm{~nm}$ ). When cholesterol reacts with alcohol, it undergoes esterification and no fluorescence occurs. The MIC represents the concentrations of alcohol and other chemicals below which fluorescence is not detected.

\section{Dried sea firefly luciferase}

The bioluminescence of sea firefly $(460 \mathrm{~nm})$ is induced by a reaction in which luciferin is oxidized by the $\mathrm{O}_{2}$ dissolved in the water under the catalytic action of the enzyme luciferase. The bioluminescence emission experiment was conducted according to the experimental procedure by Toya and Ito. ${ }^{(27}$

First, $0.1 \mathrm{~g}$ of dried sea firefly was pulverized thoroughly in a mortar. Immediately after mixing the pulverized, dried sea firefly with a $1 \mathrm{~mL}$ alcohol at $30^{\circ} \mathrm{C}$, the bioluminescence was measured with the light detector. ${ }^{(28)}$ The light detector converts light intensity to sound intensity. The light detector has a high sensitivity to blue light $(460 \mathrm{~nm})$ and was calibrated with a fluorescence spectrometer. It detected bioluminescence from $0.1 \mathrm{~g}$ of ground dried sea firefly mixed with $1 \mathrm{~L}$ of distilled water. The MIC was set to be the alcohol concentration at which the sound intensity became the background noise level.

Considering the good reproducibility of MIC measured in 10 experiments, the variation in the concentrations of luciferin and enzyme luciferase between the experiments was considered negligible.

\section{Results}

No difference was observed in the MIC values measured in the 10 experiments in this study. This suggests that the measurement data were highly reproducible. Therefore, error bars are not plotted in Figures 1-4 shown below.

\section{Minimum inhibition concentration (MIC) by alcohol for dry yeast fermentation and cholesterol stability at $30^{\circ} \mathrm{C}$ and $39^{\circ} \mathrm{C}$}

The extent to which the MIC for the dry yeast fermentation and the stability of cholesterol depends on the chain length of alcohol at $30^{\circ} \mathrm{C}$ and $39^{\circ} \mathrm{C}$ are shown in Figures 1 and 2 , respectively.

The MIC for dry yeast fermentation decreased with chain length up to $\mathrm{C}_{12}$ at $30^{\circ} \mathrm{C}$. This is consistent with the lipophilicity/hydrophobicity. Furthermore, the cut-off region was observed at $\mathrm{C}_{13}$ and $\mathrm{C}_{14}$. The anesthetic cut-off is a wellknown phenomenon at $\mathrm{C} \geq 13$. $^{(16)}$ This mechanism has yet to be solved. Figure 1 depicts a similar cut-off phenomenon in the inhibition of dry yeast fermentation.

Moreover, the $\mathrm{MIC}$ was measured at $\mathrm{C}_{13}$ and $\mathrm{C}_{14}$ at $39^{\circ} \mathrm{C}$, but not at $\mathrm{C}_{15}$ and $\mathrm{C}_{16}$. That is, the cut-off region was shifted to a longer chain length range of alcohol at $39^{\circ} \mathrm{C}$. 


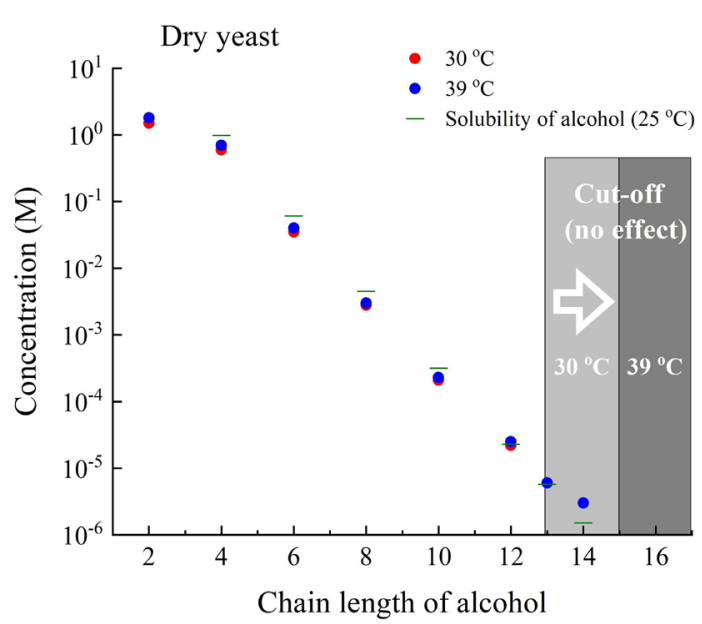

Fig. 1. Dependence of the MIC for dry yeast fermentation on the chain length of alcohol and solubility of alcohol in water $^{(32)}$

The MIC for the stability of cholesterol was slightly smaller than that for dry yeast fermentation, but the trend of the former was the same as that of the latter. That is, the MIC decreased with the chain length of alcohol. There was a cut-off region at a long-chain range, and the threshold of the cut-off region shifted to a longer chain length at $39^{\circ} \mathrm{C}$.

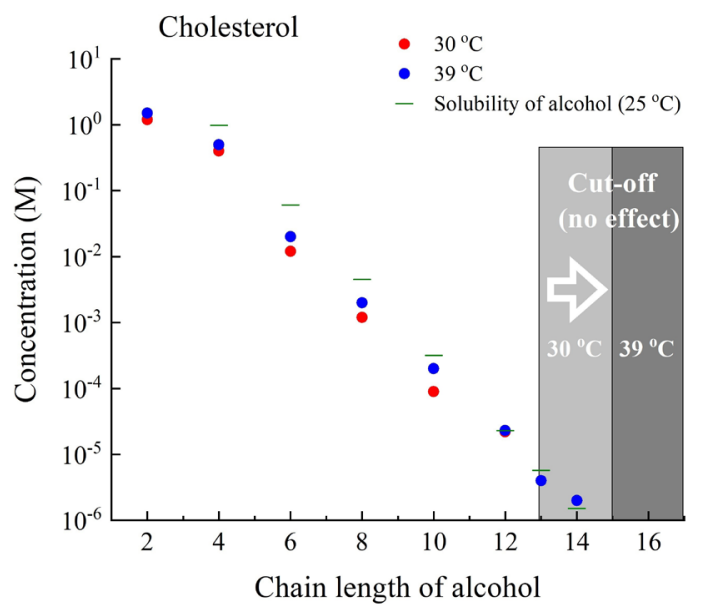

Fig. 2. Dependence of the MIC for cholesterol stability on the chain length of alcohol and solubility of alcohol in water. ${ }^{(32)}$

In the experiment with cholesterol, alcohol directly reacted with cholesterol in the solution. Further, to inhibit the dry yeast fermentation, alcohol had to interact with mannoprotein, $\beta$-glucan, chitin, and envelope. ${ }^{(29)}$ This may be why the MIC for cholesterol was slightly smaller than that for dry yeast.

\section{Minimum inhibition concentration (MIC) by diols and cetyltrimethylammonium chloride and stearyltrimethylammonium chloride for dry yeast fermentation and cholesterol stability at $30^{\circ} \mathrm{C}$}

Figure 3 depicts the MIC by diol at $30{ }^{\circ} \mathrm{C}$. The MIC decreased as the diol chain length increased. For both dry yeast fermentation and cholesterol stability, the MIC of diol was nearly equal to that of alcohol. The cut-off region was observed at $\mathrm{C}_{15}$ and higher at $30^{\circ} \mathrm{C}$.

Furthermore, it was also found that cetyltrimethylammonium chloride $\left(\mathrm{C}_{16}\right)$ and stearyltrimethylammonium chloride $\left(\mathrm{C}_{18}\right)$ inhibited the dry yeast fermentation and cholesterol stability at $30^{\circ} \mathrm{C}$.

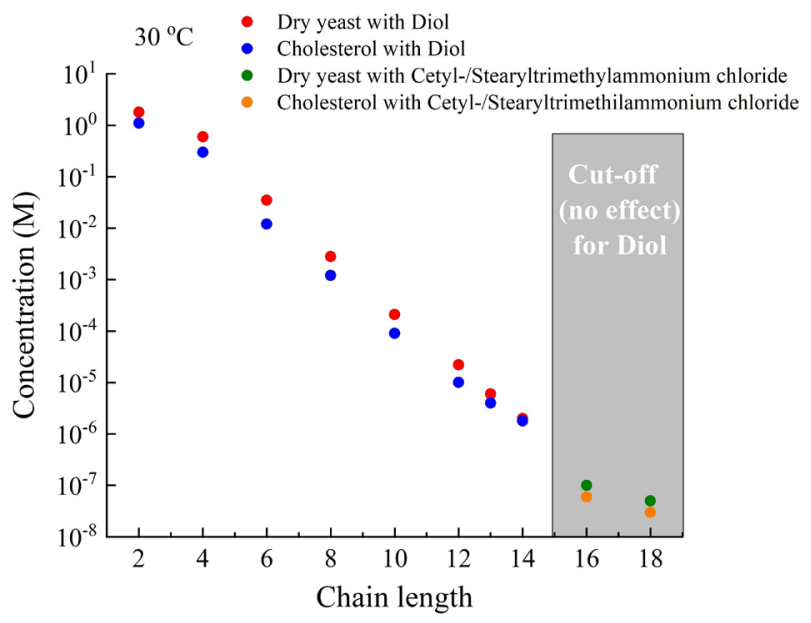

Fig. 3. Dependence of the MIC for dry yeast fermentation and cholesterol stability on the chain length of the diol. The MIC values for cetyltrimethylammonium chloride and stearyltrimethylammonium chloride are included.

\section{Minimum inhibition concentration (MIC) by alcohol for dried sea firefly at $30^{\circ} \mathrm{C}$}

The dependence of MIC for the bioluminescence of dried sea fireflies on the chain length of alcohol at $30{ }^{\circ} \mathrm{C}$ is shown in Figure 4. The MIC of alcohol decreased with chain length up to $\mathrm{C}_{14}$, with the cut-off region observed at $\mathrm{C}_{15}$ and $\mathrm{C}_{16}$. The MIC for bioluminescence was lower than the MIC for dry yeast fermentation and alcohol-induced cholesterol stability.

As Oba et al. ${ }^{(30)}$ and Suzuki et al. ${ }^{(31)}$ used firefly luciferase, the sea firefly luciferase is considered to have high sensitivity for alcohol. Hence, the MIC value for bioluminescence was smaller than that for dry yeast fermentation and cholesterol stability.

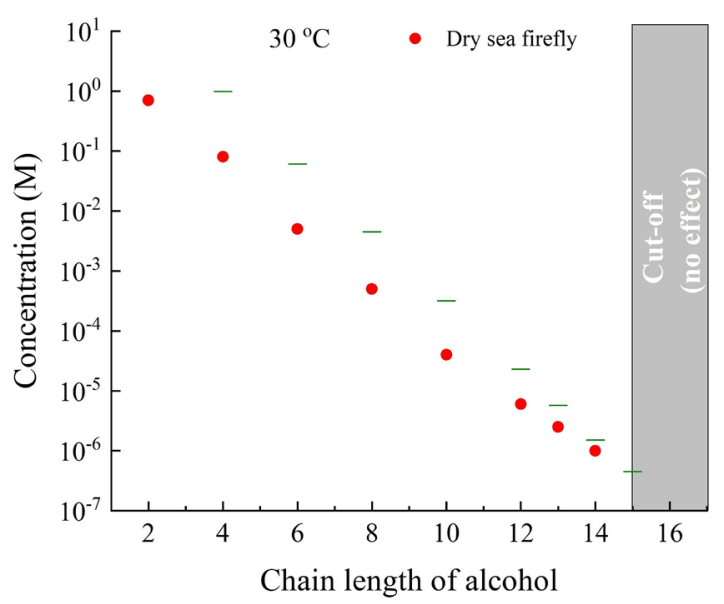

Fig. 4. Dependence of the MIC for the bioluminescence of dried sea firefly on the chain length of alcohol at $30^{\circ} \mathrm{C}$ and solubility of alcohol in water. ${ }^{(32)}$ 


\section{Discussion}

\section{Possible reasons for the origin of the cut-off region}

Our study found (a) that the MIC decreased with the chain length of alcohols and diols in all our experiments and (b) that the cut-off region was clearly observed for longer chain alcohols and diols under our experimental conditions.

Figures 1 and 2 also show the plots of the solubility of alcohol in water at $25{ }^{\circ} \mathrm{C}$. $^{(32)}$ The solubility of alcohol at $30^{\circ} \mathrm{C}$ and $39^{\circ} \mathrm{C}$ is unlikely to be lower than the solubility at $25^{\circ} \mathrm{C}$. The fermentation activity of dry yeast is hindered at high temperatures. In daily life, we do not use disinfectants at high temperatures such as $50{ }^{\circ} \mathrm{C}$. The melting points of 1-tridecanol and 1-tetradecanol are $32.5^{\circ} \mathrm{C}$ and $37.7^{\circ} \mathrm{C}$, respectively, whereas those of 1-pentadecanol and 1-hexadecanole are $45.5{ }^{\circ} \mathrm{C}$ and $49.3{ }^{\circ} \mathrm{C}$, respectively. The solubility of solid alcohol increases upon melting. The melting point of alcohols with $\mathrm{C} \leq 12$ is lower than $25^{\circ} \mathrm{C}$. Therefore, a temperature of $39^{\circ} \mathrm{C}$ was selected in this study.

From Figures 1 and 2, the MIC values at $\mathrm{C} \leq 10$ at $30^{\circ} \mathrm{C}$ and $39{ }^{\circ} \mathrm{C}$ were found to be smaller than the solubility of alcohol at $25^{\circ} \mathrm{C}$; the $\mathrm{MIC}$ values at $\mathrm{C}_{12}$ at $30^{\circ} \mathrm{C}$ and $39^{\circ} \mathrm{C}$ were almost equal to the solubility at $25{ }^{\circ} \mathrm{C}$. According to Bell, (32) the logarithm of the solubility of $n$-alcohol in water at $25^{\circ} \mathrm{C}$ changes almost linearly with the chain length of alcohol up to $\mathrm{C}_{16}$. When the temperature is raised to $30^{\circ} \mathrm{C}$ and $39^{\circ} \mathrm{C}$, this linearity is unlikely to change. Assuming that both the logarithm of solubility at $30^{\circ} \mathrm{C}$ and the logarithm of MIC at $30^{\circ} \mathrm{C}$ change linearly with the length of the alcohol chain, two linear plots intersect between $\mathrm{C}_{12}$ and $\mathrm{C}_{13}$. Because solubility increases at $39{ }^{\circ} \mathrm{C}$, the linear plot of solubility at $39^{\circ} \mathrm{C}$ between $\mathrm{C}_{14}$ and $\mathrm{C}_{15}$ may intersect the $\mathrm{MIC}$ at $39^{\circ} \mathrm{C}$.

In Figure 3, we used chemicals with higher solubility than alcohol. The MIC values for diol at $30^{\circ} \mathrm{C}$ were almost identical to those for alcohol at $30{ }^{\circ} \mathrm{C}$. We could not find the quantitative value of solubility of diol up to $\mathrm{C}_{16}$ in water at $25{ }^{\circ} \mathrm{C}$ or $30{ }^{\circ} \mathrm{C}$ in any research papers. A straightchain diol, however, has a higher solubility than straightchain alcohol. Therefore, if the logarithm of diol solubility changes linearly with chain length, we can assume that the diol solubility linear plot intersects with the MIC for dry yeast fermentation and the stability of cholesterol between $\mathrm{C}_{14}$ and $\mathrm{C}_{15}$. For cetyltrimethylammonium chloride and stearyltrimethylammonium chloride, which have much higher water solubility than alcohols and diols, the MIC was discovered even at $\mathrm{C}_{16}$ and $\mathrm{C}_{18}$.

We also used the sea firefly luciferase, which is highly sensitive to alcohol (Figure 4). Then, we found that the MIC was less than that for dry yeast or cholesterol. The MIC was smaller than the solubility of alcohol up to $\mathrm{C}_{14}$. We considered that the linear plot of solubility of alcohol at $30^{\circ} \mathrm{C}$ intersects the linear plot of the MIC between $\mathrm{C}_{14}$ and $\mathrm{C}_{15}$.

To summarize, for alcohol to inhibit the fermentation of dry yeast and the stability of cholesterol and sea firefly luciferase, it must be in a liquid state. In a liquid state, the longer the chain, the lower the MIC. When the solubility is smaller than the MIC, the cut-off phenomenon occurs.

\section{Potential activity of long-chain alcohols}

In this study, we investigated the interaction of alcohol with the dry yeast, cholesterol, and sea firefly luciferase, not with the real viruses. However, dry yeast was used to study disinfection, antimicrobial action, and infectious diseases. Further, cholesterol is one of the main components of the viral envelope. As a result, the findings of this study suggest that long-chain alcohols may be suitable for disinfection and that the longer the chain of the alcohol, the lower the concentration required for disinfection. Of course, ethanol and isopropanol are useful for disinfection. However, if we need to disinfect wide surfaces such as walls, floors, and ceilings of rooms, longchain alcohols are convenient, effective, and useful because their costs are lower, and roughening of hands by alcohol can be prevented because of the very low concentration required.

The mechanisms of disinfection with alcohol against viruses and bacterias are not completely elucidated. However, possible mechanisms are as follows: ${ }^{(33-35)}$ (a) alcohol passes through the viral envelope/bacteria membrane and penetrates the cell, increasing the pressure inside the cell. As a result, the cells are destroyed, and the virus is eliminated. (b) The cholesterol reacts with alcohol, converting to ester. Therefore, the envelope is punctured, allowing the contents of the cell to leak out, killing the virus. Alcohol must be in liquid form to work in this manner. Solid alcohol cannot enter the cell or interact with cholesterol. In terms of phenomenology, this is consistent with the possible reasons for the origin of cut-off regions discussed above.

The real viruses were not used to prove the activity of long-chain alcohols and the presence of a cut-off region. However, we consider that the possibility of the potential activity of long-chain alcohols as disinfectants were qualitatively demonstrated. Therefore, further study with real viruses is desired.

\section{Conclusion}

The MIC for the dry yeast fermentation and for the stability of cholesterol and sea firefly luciferase decreased with the chain length of the alcohol used. However, the cutoff phenomenon was observed at longer chain lengths. One possible explanation for the cut-off phenomenon is that alcohol is either liquid or solid. Only liquid alcohol can inhibit dry yeast fermentation and maintain the stability of cholesterol and sea firefly luciferase. The results obtained in this study suggest that long-chain alcohols may have a potential activity as a disinfectant.

\section{Acknowledgments}

We would like to express our great thanks to Mrs. Beth Wilson, Oakville Christian School, for her valuable supports throughout our research.

\section{Disclaimers}

The views expressed in the submitted article are our own and not an official position of the institution. 


\section{Conflict of Interests} interest.

The authors declare that they have no conflicts of

\section{References}

1. Government of Ontario. COVID-19: Stop the spread [Internet]. [Cited 2021 Oct 2]. Available from: https://www. ontario.ca/page/covid-19-stop-spread.

2. Boyce JM. Alcohols as Surface Disinfectants in Healthcare Settings. Infect Control Hosp Epidemiol. 2018 Mar;39(3):323-328. doi: 10.1017/ice.2017.301.

3. Government of Canada. Coronavirus disease (COVID-19): Prevention and risks [Internet]. [Cited 2021 Oct 2]. Available from: https://www.canada.ca/en/publichealth/services/diseases/2019-novel-coronavirus-infection/ prevention-risks.html.

4. Centers for Disease Control and Prevention. Hand hygiene recommendations. Guidance for healthcare providers about hand hygiene and COVID-19 [Internet]. [Cited 2021 Oct 2]. Available from: https://www.cdc.gov/coronavirus/2019-ncov/ hcp/hand-hygiene.html.

5. Jing JLJ, Pei Yi T, Bose RJC, McCarthy JR, Tharmalingam N, Madheswaran T. Hand Sanitizers: A Review on Formulation Aspects, Adverse Effects, and Regulations. Int J Environ Res Public Health. 2020 May 11;17(9):3326. doi: 10.3390/ ijerph17093326.

6. Kratzel A, Todt D, V'kovski P, Steiner S, Gultom M, Thao TTN, Ebert N, Holwerda M, Steinmann J, Niemeyer D, Dijkman R, Kampf G, Drosten C, Steinmann E, Thiel $\mathrm{V}$, Pfaender S. Inactivation of Severe Acute Respiratory Syndrome Coronavirus 2 by WHO-Recommended Hand Rub Formulations and Alcohols. Emerg Infect Dis. 2020 Jul;26(7):1592-1595. doi: 10.3201/eid2607.200915.

7. Yip L, Bixler D, Brooks DE, Clarke KR, Datta SD, Dudley S Jr, Komatsu KK, Lind JN, Mayette A, Melgar M, Pindyck T, Schmit KM, Seifert SA, Shirazi FM, Smolinske SC, Warrick BJ, Chang A. Serious Adverse Health Events, Including Death, Associated with Ingesting Alcohol-Based Hand Sanitizers Containing Methanol - Arizona and New Mexico, May-June 2020. MMWR Morb Mortal Wkly Rep. 2020 Aug 14;69(32):1070-1073. doi: 10.15585/mmwr. mm6932e1.

8. Shalbafan M, Khademoreza N. What we can learn from COVID-19 outbreak in Iran about the importance of alcohol use education. Am J Drug Alcohol Abuse. 2020 May 3;46(3):385-386. doi: 10.1080/00952990.2020.1753759.

9. Kubo I, Muroi H, Kubo A. Structural functions of antimicrobial long-chain alcohols and phenols. Bioorg Med Chem. 1995 Jul;3(7):873-80. doi: 10.1016/09680896(95)00081-q.

10. Mukherjee K, Tribedi P, Mukhopadhyay B, Sil AK. Antibacterial activity of long-chain fatty alcohols against mycobacteria. FEMS Microbiol Lett. 2013 Jan;338(2):17783. doi: 10.1111/1574-6968.12043.

11. Fletcher RD, Gilbertson JR, Albers AC, White JD. Inactivation of mycoplasmas by long-chain alcohols. Antimicrob Agents Chemother. 1981 May;19(5):917-21. doi: 10.1128/AAC.19.5.917.

12. Ingram LO, Vreeland NS. Differential effects of ethanol and hexanol on the Escherichia coli cell envelope. J Bacteriol.
1980 Nov;144(2):481-8. doi: 10.1128/jb.144.2.481-488.1980. 13. Gill CO, Ratledge C. Toxicity of $n$-alkanes, $n$-alk-1enes, $n$-alkan-1-ols and $n$-alkyl-1-bromides towards yeasts. Microbiology. 1972;72(1):165-72. doi: 10.1099/0022128772-1-165.

14. Teh JS. Toxicity of short-chain fatty acids and alcohols towards Cladosporium resinae. Appl Microbiol. 1974 Nov;28(5):840-4. doi: 10.1128/am.28.5.840-844.1974.

15. Kato N, Shibasaki I. The antimicrobial characteristics of 1-alkanols. J Antibact Antifung Agents. 1980;8:325-31.

16. Pringle MJ, Brown KB, Miller KW. Can the lipid theories of anesthesia account for the cutoff in anesthetic potency in homologous series of alcohols? Mol Pharmacol. 1981 Jan;19(1):49-55.

17. Zapata-Morin PA, Sierra-Valdez FJ, Ruiz-Suárez JC. The cut-off effect of n-alcohols in lipid rafts: A lipid-dependent

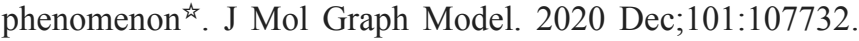
doi: 10.1016/j.jmgm.2020.107732.

18. Brosnan RJ, Pham TL. Anesthetic-sensitive ion channel modulation is associated with a molar water solubility cut-off. BMC Pharmacol Toxicol. 2018 Sep 14;19(1):57. doi: 10.1186/ s40360-018-0244-z.

19. Kubo I, Fujita T, Kubo A, Fujita Ki. Modes of antifungal action of alkanols against Saccharomyces cerevisiae. Bioorg Med Chem. 2003 Mar 20;11(6):1117-22. doi: 10.1016/s09680896(02)00453-4.

20. Bordeleau LJ, Gailis L, Fournier D, Morissette M, Di Paolo T, Daleau P. Cut-off phenomenon in the protective effect of alcohols against lysophosphatidylcholine-induced calcium overload. Pflugers Arch. 2005 Aug;450(5):292-7. doi: 10.1007/s00424-005-1425-3.

21. Williams AA, Sugandhi EW, Macri RV, Falkinham JO 3rd, Gandour RD. Antimicrobial activity of longchain, water-soluble, dendritic tricarboxylato amphiphiles. J Antimicrob Chemother. 2007 Mar;59(3):451-8. doi: $10.1093 / \mathrm{jac} / \mathrm{dk} 1503$.

22. Kamaya H, Matubayasi N, Ueda I. Biphasic effect of longchain n-alkanols on the main-phase transition of phospholipid vesicle membranes. J Phys Chem. 1984;88(4):797-800. doi: 10.1021/j150648a036.

23. Veenstra G, Webb C, Sanderson H, Belanger SE, Fisk P, Nielsen A, Kasai Y, Willing A, Dyer S, Penney D, Certa H, Stanton K, Sedlak R. Human health risk assessment of long chain alcohols. Ecotoxicol Environ Saf. 2009 May;72(4):101630. doi: 10.1016/j.ecoenv.2008.07.012.

24. Kikuchi K. [Various topics concerning infectious diseases (9) Microbiological experiments in the home (2)]. 感染症四方山話(9): 家庭でできる微生物実験その2. The Chem Times. 2014;233:18-23. Japanese. Available from: https://www.kanto.co.jp/dcms_media/other/series_pdf09. pdf.

25. Ishijima $\mathrm{S}, \mathrm{Abe} \mathrm{S}$. [Safe and easy manual for measuring antifungal activity]. 安全で簡易な抗真菌活性の測定マ ニュアル. Med Mycol Research. 2012;3(1):7-16. Japanese. Available from: https://appsv.main.teikyo-u.ac.jp/tosho/ ishinkin3-1-04.pdf.

26. Miriyama H. [Attenuation of rice blast fungus and development of biological control materials using dry yeast and mycovirus]. パン酵母を利用したイネいもち病菌 弱毒化マイコウイルスの生物防除資材としての実用 化研究. Presentation material at NEDO-Tokyo University of Agriculture and Technology Symposium [Internet]. [cited 2021 Oct 2]. Available from: https://www.nedo.go.jp/ 
content/100080343.pdf. Japanese.

27. Toya Y, Ito H. [Evaluation of the educational effect of the experimental demonstration for bioluminescence by using freeze-dried Vargula (formerly Cypridina) hilgendorfii bodies as a teaching material]. 凍結乾燥ウミホタル生物発光教材 を使用した実践とその教育効果の評価. Research Report of Aichi University of Education. 2008;57:65-72. Japanese: Available from: https://aue.repo.nii.ac.jp/?action=repository_ action_common_download\&item_id=669\&item no $=1 \&$ attribute $\mathrm{id}=\overline{1} 5 \&$ file no $=1$.

28. Nagasaki K. Underwater communication with blue light. Can Sci Fair J. [cited 2021 Oct 2]; 2020;3(2). Available from https:/csfjournal.com/volume-3-issue-2/2020/10/26/ underwater-communication-with-blue-light.

29. Fesel PH, Zuccaro A. $\beta$-glucan: Crucial component of the fungal cell wall and elusive MAMP in plants. Fungal Genet Biol. 2016 May;90:53-60. doi: 10.1016/j.fgb.2015.12.004.

30. Oba Y, Ojika M, Inouye S. Firefly luciferase is a bifunctional enzyme: ATP-dependent monooxygenase and a long chain fatty acyl-CoA synthetase. FEBS Lett. 2003 Apr 10;540(1-3):251-4. doi: 10.1016/s0014-5793(03)00272-2.
31. Suzuki H, Kawarabayasi Y, Kondo J, Abe T, Kimura S, Hashimoto T, et al. Structure and regulation of rat long-chain acyl-CoA synthetase. J Biol Chem. 1990;265(15):8681-5. doi: 10.1016/S0021-9258(19)38942-2.

32. Bell GH. Solubility of normal aliphatic acids, alcohols and alkanes in water. Chem Phys Lipids. 1973;10(1):1-10. doi: 10.1016/0009-3084(73)90036-4.

33. Lin Q, Lim JYC, Xue K, Yew PYM, Owh C, Chee PL, et al. Sanitizing agents for virus inactivation and disinfection. View [Internet] 2020 May [cited 2021 Oct 2]. Available from: https://onlinelibrary.wiley.com/doi/10.1002/viw2.16.

34. Food Analysis Technology Center [Internet]. [Technology for using alcohol to control microorganisms in food factories]. 食品工場の微生物制御へのアルコールの利用技術 [cited 2021 Oct 2]. Japanese. Available from: http://www.mac.or.jp/ mail/120601/04.shtml.

35. Shimmei A. Influence of ethanol concentration on bactericidal and virucidal activities [Internet]. Ph.D. Thesis: Tokyo Healthcare University; 2019 [cited 2021 Oct 3]. Japanese. Available from http://www.thcu.ac.jp/uploads/ imgs/20190605090207.pdf. 